https://doi.org/10.3126/pragya.v7i1.35035

\title{
Problems and Prospects of the Coffee Cultivation in Nepal with Special Reference to Hokse Bazaar of Kavrepalanchok District
}

\author{
Dahal Ananta Raj (Ph. D. Scholar)
}

\begin{abstract}
s
Nepal has much diversified climate topographical condition; vareity of agricultures' farming is possible in different climate. For the development of the Nepalese agriculture different cash crops played a vital role in the different geographical and climate condition. Middle hilly area from eastern part to western part of Nepal climate is suitable for Coffee farming. This research examines the problems and prospects of the coffee cultivation in Nepal with special reference to Hokse Bazaar of Kevrepalanchok district. The objectives of this study are to analyze the present situation of Coffee cultivation in the sample areas population and to analyze problems and prospects of the coffee cultivation in the areas. Both primary and secondary data are used the sources of information. Descriptive research design has been used for the processes of data analysis. This research shows the increasing Coffee farming people who help to improve the local people's economic status and the protection of landslides as well as environment. There are many problems such as technical, economy for investment, proper market and Coffee refinement. To solve different problems of Coffee cultivation government of Nepal must support them.
\end{abstract}

Keyword: problem, prospect, coffee, cultivation, climate, agriculture

\section{Introduction}

Nepal has much diversified climate topographical conditions, comprising of the highest peak Mt. Everest (8,848m.) and down to 60m at Kechana in Jhapa district, the Far Easten part of Nepal. Nepal occupies 68 percent (100,083 sq.km.) in Hilly region is formed by Mahabharat range soaring up to 4,877m and 17 percent (25,021 sq.km.). In Terai region and remaining 15 percent (22,077 sq.km.) is Himalayan region covered by snow throughout the year with solitary precipices, rock and glorious peaks (CBS 2001).

Economically, Nepal is one of the poorest and underdeveloped countries in the world. Agriculture is the backbone of Nepalese economy but, here is not used the modern farming technology, due to the poverty, lack of education, transportation, communication and political instability. 
In Nepalese agriculture sector, the crops are divided into four broad categories. They are cereal crops, cash crops, pulse crops and horticulture. Paddy, maize, Wheat, millet arecereal crops,Coffee, tea, jute, sugarcane, tobacco, mustard, etc. are cash crops,Lentil, pea, bean, black gram, grass gram, horse gram etc. are pulse crops andapple, mango, orange, lemon, banana, jackfruit etc. arehorticultures crops.

The history of the coffee plantation beginning from Aanpchaurrural municipalities of Gulmi district in province five of Nepal, Coffee cultivation is confined mostly to hilly treats. A well distributed annual rainfall is preferable to coffee, which is one of the important cash crops. Now days, almost all people in the world drink coffee but it is not in demand like tea in Nepal. Its consumption is mainly confined to urban areas and in affluent societies. Globally, increasing demand rate of coffee expanding the market so that many countries have been involving in coffee farming.

Coffee production plays an important role in poverty reduction and thereby sustainable rural development of Nepal. It is the major source of foreign currency. In 1992 A.D. Gulmi, Arghakhanchi Rural Development Project (GARDP Phase II) carried out a study concluding that coffee was 2.3 times more profitable than rice, 3.3 times than maize and 4.0 times than wheat (Sapkota, 1998).

The Coffee farming is better than other farming like paddy, maize and sugarcane with respect to the production and return, use of waste land.Coffee is relatively a new cash crop started growing in Nepal almost with inorganic product, without useing any fertilizers and pesticides. It could be an important occupation in the rural economy with massive participation of marginal, poor and down trodden class of the rural communities. Additionally, its impact is seen positive not only economically but also socioenvironmentally. Scenic beauty, greenness, conservation of forest and water resource, control of landslide and flood are its environmental contributionsin the mid-hills of Nepal.

Nepalese coffee that is virtually free from the inorganic fertilizers and pesticides could occupy the good position among the organic coffee in the world. But Nepal should carefully observe the international scenario of price and demand in the world coffee markets and be competitive in of price, quality and quantity in order to raise the perspective of Nepalese coffee in the world market. Similarly, acquiring the official organic certification and production of the specialty coffees will also enhance the Nepalese coffee market.

In the least developed countries like Nepal, coffee production plays an important part in rural development and the industry's fortunes have a direct impact on the livelihood of many small farmers, Coffee production is an extremely important in generation of employment and overriding importance to the social structure and development of most producing 
countries. Nepal can export coffee and initiate sustainable economic development with environmental balance, employment generation and open new horizons for fundamental development.

The major stakeholders working in the production, development, processing and marketing of coffee are: Central Coffee Cooperative Union Limited (CCU), National Coffee Producers Association (NCPA), Planet Nepal Inca, Gourishankar Organic Coffee Association (GOCA), Nepal Coffee Trade Association (NCTA), Royal Everest Coffee Mills (P) Ltd (RECMP Ltd), High land Coffee (HLC), Department of Tea and Coffee Development (DTCD) and National Tea and Coffee Development Board (NTCBD).

Government of Nepal has approved and implemented National Coffee Policy 2003 as per the intention of National Tea and Coffee Development Board Act 1992 for the development of coffee as a reliable source of income in the enhancement of opportunity of employment and earning of foreign currency by the increase of private sector in the production, processing and commercial transaction of coffee with the sustainable and systematic utilization of available resources and opportunities in the country.

The commercial farming of coffee in Nepal began only 25 years ago. The demand of Nepali organic coffee in the international market had gone up significantly.Some mid hill districts like Gulmi, Palpa, Kaski, Gorkha, Lalitpur, Tanahu, Kavre, Sindhupalchok, Lamjung, Syangja, Baglung, are successfully growing coffee farming. Nepalese coffee productions trend is positively increasing which show farmers are interested to coffee farming and they produced organic coffee which is most demanded in the American and European Country.

\section{Objectives}

The main objectives of this research articles are as follows:

-To analyze the present situation of Coffee cultivation in sample areas population.

-To analyze the problems and prospects of the coffee cultivation in the sample areas.

\section{Research Methodology}

A number of steps were fallowed to accomplish the present study.

\section{Research Design}

This research has attempted to analyze problems and prospect of coffee production in Nepal with reference to Hokse Bazaar of Panchkhal Municipalities Kavrepalanchok. This research based on both primary and secondary information using quantitative and qualitative methods. The research processes has adopted descriptive research design. 
In social science research, field work is the central and important method of collecting the primary information. Secondary information also plays an important role while analyzing and giving inference of some empirical knowledge (Adhikari, 2011). The study is based on both primary and secondary data. Both qualitative and quantitative approaches were used for data analysis. As for the primary data collection semi-structured questionnaires were used.

\section{Sampling Design and Sample Size}

There are more than 30 districts cultivating coffee in Nepal. On the purpose of this research Hokse Bazaar of Nomo Buddha Municipality of Karvepolanchoak district was selected for field study. From the total 298 households of coffee farmer of the sample area 45 households have been selected by the sample random methods as sample of the population for primary information collection.

\section{Empirical Result and Discussion}

\section{Present Situation of Coffee Cultivation in Sample Area}

\section{Area of Land Holds in Sample Area Households}

Different farmers have different size of land in the sample area. Landholding situation of the different householder's people in the sample area has been shown from the help of the following table as:

Table:1. Land size, Households Frequency and Coffee Production Area

\begin{tabular}{|l|l|l|l|l|}
\hline Size of Land & HHs No. & Area & Percent & Average Size \\
\hline$<1$ ha. & 22 & 3.35 & 26.22 & 0.15 \\
\hline $1-2$ ha. & 14 & 6.35 & 49.68 & 0.45 \\
\hline$>2$ ha. Total & 45 & 3.08 & 24.10 & 0.34 \\
\hline & 9 & 12.78 & 100.00 & 0.284 \\
\hline
\end{tabular}

Source: Field Survey, 2016

The table 1 shows the land holding situation of the sample area. There is high variation in land distribution; local poor are also encouraged to cultivate coffee farming. Out of the total 12.78ha Coffee cultivated land, poor households, have cultivated coffee in 26.22 percent (3.35 ha) land and average coffee cultivated land is 0.15 ha. Per household which is largest than others. 


\section{Area, Yield and Production of Coffee}

The climate condition of the study area is favorable for coffee production; the production has not been increasing significantly before 5/10 year ago as its potentiality. Because of the various problems have been faced by coffee growers i.e., price failure, dilemma in growing at that time of coffee production was exchanged with salt by the same amount. Area yield and coffee production are as fallows.

Table: 2. Area Yield and Production of coffee

\begin{tabular}{|c|c|c|c|c|c|}
\hline \multirow{2}{*}{$\begin{array}{c}\text { Area in } \\
\text { hectare }\end{array}$} & \multicolumn{3}{|c|}{ No. of Plants } & $\begin{array}{c}\text { Production in } \\
\text { kg. }\end{array}$ & $\begin{array}{c}\text { Value in } \\
\text { Rs. }\end{array}$ \\
\cline { 2 - 4 } & Productive & Unproductive & Total & & \\
\hline 12.78 & $\begin{array}{c}2234 \\
(40.90)\end{array}$ & $\begin{array}{c}3228 \\
(59.10)\end{array}$ & $\begin{array}{c}5462 \\
(100.00)\end{array}$ & 3115 & 280,350 \\
& & & & \\
\hline
\end{tabular}

Source: Field Survey, 2016

In table 2 shows that from the total sampled plants 40.90 percent productive and 59.10 percent unproductive. Total production of coffee in the study area (sampled area) was about 3115kg.in the year 2013/14A.D.

In the study area, it is found by field observation that most of the plants are unproductive, even productive plants have low production because they are just starting to provide returns.

\section{Utilization of Coffee}

The purposes of coffee production in the study area have been shown by the helps of the following table below.

Table: 3. Utilization of coffee

\begin{tabular}{|c|c|c|c|}
\hline S.N. & Use of coffee & Quantity & Percent \\
\hline 1. & Self-consumption & 103 & 3.30 \\
\hline 2. & Distribution as gifts & 113 & 3.62 \\
\hline 3. & Wastage (damage) & 157 & 5.05 \\
\hline 4. & Sale & 2742 & 88.03 \\
\hline & Total & 3115 & 100.00 \\
\hline
\end{tabular}

Source: Field Survey, 2016

In table 3 shows that from the total production of the Coffee in the sample area 3.3 percent are used for self-consumption, 3.62 percent are used for distribution as gift, 5.05 percent are damaged and 88.03 percent are sale. The table shows that the maximum percent of their production were sold in the market.

\section{Marketing of Coffee}

Agricultural production beyond producer's requirement necessitates the availability of efficient marketing system. Something happens to the coffee production and efficient marketing system gives incentive to the coffee growers to increase their production. Thus, 
marketing system plays a vital role to develop the coffee production sector also. Coffee market and marketing situation are express as fallows.

Table: 4. Sale of Coffee Production

\begin{tabular}{|r|c|c|}
\hline \multicolumn{1}{|c|}{ Description } & Frequency of HHs & Price per kg. in Rs. \\
\hline Sold to the traders at market & 28.88 & 95 \\
\hline Sold to the traders at home & 71.12 & 90 \\
\hline Total & 100.00 & \\
\hline
\end{tabular}

Source: Field Survey, 2016

The table 4 shows the sales situation of Coffee in the sample area. The main traders (contractor and mediator through home) of the study area are, district co-operative Kavre, Coffee producer Association, Pancklhal Kavre Coffee Company. Only 28.88 percent of their total products are sales in market, which had provided high rate than at home for producers.

\section{Problems and Prospectus of Coffee Farming Problems of Coffee Farming}

\section{General Problem}

Coffee cultivation has been a new experience for traditional farmers. On the other hand, most farmers have no knowledge about coffee farming and on the other hand, government and other agency have not been able to provide basic infrastructure on coffee farming. General problem of coffee farming in Nepal has express from the help of the following table.

\section{Table: 5.General Problems of Coffee Farming}

\begin{tabular}{|l|c|c|}
\hline \multicolumn{1}{|c|}{ Problems } & Frequency of HHs & Percent \\
\hline Knowledge and Training & 42 & 93.33 \\
\hline Technical support & 39 & 86.66 \\
\hline Leadership Development & 36 & 80.00 \\
\hline Shortage and Processing Facilities & 33 & 73.33 \\
\hline Diseases, Insect and Pests & 30 & 66.66 \\
\hline Poverty & 26 & 57.77 \\
\hline Institutional Credit & 21 & 46.66 \\
\hline Supply of Labor & 17 & 37.77 \\
\hline Improved Saplings & 14 & 31.12 \\
\hline Transportation & 9 & 20.00 \\
\hline
\end{tabular}




\begin{tabular}{|l|c|c|}
\hline Shortage of Irrigation & 2 & 4.45 \\
\hline Land Scarcity & 3 & 6.66 \\
\hline Supply of the Compost & 2 & 4.45 \\
\hline
\end{tabular}

Source: Field Survey, 2016

The table 5 shows that the different problems of coffee farming in sample area of this study. From the information of the respondent, 93.33 percent felling lack of knowledge and training,86.66 percent felling the technical support and subsidy,80 percent felling leadership development, 73.33 percent felling storage and processing facilities, 66.66 percent felling of theinsect,57.77 percent felling of poverty. 46.66 percent felling of institutional credit,37.77 percent felling supply of labor,31 percent felling improved saplings,31.12 percent felling transportation, 20.00 percent felling shortage of irrigation, 4.45 percent felling land scarcity 6.66 percent and problem of supply of the compost 4.45 percent in the study area.

\section{Problem of Diseases and Insects Pests}

Coffee growers of the study area are facing so many problems of diseases and insects pests. Main problems of diseases and insects pests are as fallows.

Table: 6. Diseases and Insects Pests Found in Coffee Farming

\begin{tabular}{|l|c|c|}
\hline \multicolumn{1}{|c|}{ Diseases } & Frequency of HHs & Percent \\
\hline Hemileiavstatrix(sindureroga) & 39 & 86.66 \\
\hline Kolerognaoxia(KaloKuchineRoga) & 36 & 80.00 \\
\hline AnthoresLeucontus (setogabaro) & 42 & 93.33 \\
\hline Apatemonachus (ratogabaro) & 39 & 86.66 \\
\hline Root Knot Nematodes (CoffeekojarakoJuka) & 13 & 28.88 \\
\hline DirphyNigricoris - Oliver(yellow head borer) & 7 & 15.55 \\
\hline StephoanoderesNampei (BerrikoGabaro) & 5 & 11.11 \\
\hline Lygus Coffee China (Capp acid Borer) & 3 & 6.66 \\
\hline THilptoccrusSmarayadia-Butler(berry moth) & 2 & 4.44 \\
\hline
\end{tabular}

Source: Field Survey, 2016

Table 4.4.2 shows the main diseases found in coffee farming, which fall of leaves by blocking the respiration system of plants and reduces the coffee production to a great extent. From the total respondent 86.66percentfarmers Hemileiavstatrix(sindureroga), 80 percent farmers 'Kolerognaoxis' (kalokuhineroga), 93 percent Anthores Leucontus (setogabaro)About the insect pests, the main problem was seen the study area which also caused to reduce the coffee production to a greater amount. The main insect pest reported 
was 'AnthoresLeuconotus' (SetoGabaro) by 93.33 percent and another 'Apatemonachus' (RatoGabaro) was reported by 86.66 percent. And other are 'Root Knot Nematodes' (Coffee ko JarakoJuka), 'DirphyNigricoris-Oliver' (Yallow Head Borer), 'StephaoanoderesNampei' (BerrikoGabaro), 'Lygus Coffee China' (Capp acid Borer), 'THliptpccrus SmaraydiaButler' (Berry Moth) are 4.44 percent.

\section{Sources of Coffee Saplings}

Some experienced coffee growers who are nursery owners also reported that to achieve better production from coffee farming, the plantation of improved saplings is essential. But in the study area, Most of the coffee growers use to prepare the coffee sapling from local nurseries and few were provided the coffee saplings by the Coffee Development Center Panchkhal Coffee saplings situation had been shown as:

Table: 6.Sources of Coffee Saplings

\begin{tabular}{|c|c|c|}
\hline Sources & No of Households & Percent \\
\hline Self-prepared & 24 & 53.33 \\
\hline Local Nursery & 13 & 28.89 \\
\hline Coffee Development Center & 8 & 17.78 \\
\hline Total & 45 & 100.00 \\
\hline
\end{tabular}

Source: Field Survey, 2016

Table 6 shows the sources of coffee saplings in the study area, 53.33 percent are selfprepared the coffee saplings in own nursery, 28.89 percent had bought Coffee Development Center and 17.78 percent brought local nursery. It shows that the maximum coffee farmers are self-prepared coffee saplings in own nursery.

\section{Problems Faced on Coffee Sampling}

Sampling process of coffee is very importance for the market expansions as well as to get the high price. Sampling process the coffee some farmer are facing different problem and some are not. The following table shows that weather they are facing problem of coffee sampling.

Table: 7.Problems Faced in Availability of Coffee Saplings

\begin{tabular}{|c|c|c|}
\hline Problems & No. of Households & Percent \\
\hline Yes & 14 & 31.11 \\
\hline No & 31 & 68.89 \\
\hline Total & 45 & 100.00 \\
\hline
\end{tabular}

Source: Field Survey, 2016 
The table 7 shows that only 31.11 percent households reported that they have problems obtaining coffee saplings but about 68.89 percent of the total sampled coffee growers reported that they do not have any problem about availability of coffee saplings.

\section{Prospects}

Coffee has bright prospects in the study area as well as mid hilly region of middle part of Nepal. Economically, it is more profitable than the other traditional cereal crops. Topographically and climatically, the study area is suitable for coffee cultivation and there is no problem about transportation facility as the Araniko highway as well as Lamidanda Palanchok sub-motor way facilities it even very few sampled coffee growers reported the problem about it. So, it has better economic prospects for the cultivation of coffee farming. Thus, if all the farmers of the study area grow the coffee trees instead of other prevailing traditional food grain crops like maize, millet etc. they can certainty receive better income. Better income helps them to improve their economic status by improving educational status, health status, social status etc.

The future prospect of the coffee farming is essential growing as new enterprise. Firstly, it is needed to remove above problems. Secondly, subsidies and incentives should be regulated to supply the fund for coffee farmer. Thirdly, input subsidization and required technical guidance should be introduced. Fourthly, establishment of communication network should be considered time to time. Fifthly, convince is most needed to the farmers through encouraging them. If it is developed as single crop with lessening problems where the farmers may seek to extend alternative policies more than before.Most of the leading farmers expressed that if the sales price of cherry coffee were raised more farmers would be motivated towards this new enterprise.

\section{Socio-economic Impact of Coffee Farming}

Before coffee farming, many farmers (specially small and middle) used to take loan to maintain their subsistence but after the coffee farming they have been able to improve their life as a whole. By nature, coffee cultivation is labor intensive technology so that it has helped to reduce cultivation the unemployment problem of the rural people, to some extent. Because of its commercial benefits, the youth of the study area were found more interested in systematic coffee farming. From the benefit of coffee production, farmers of the study area have determined to plant coffee in the areas where other crops are growing, now.Local people of the study area have been involving coffee farming to improve their social condition. 


\section{Extension Services and Training}

Agriculture training is a key factor to increase potentiality of farmers and it strength skill or competence. Many training activities have been done through government extensionworkers including nursery establishment, orchard management, inter-cropping farming system, use of fertilizer, use of pesticides, use of cover crops, weed central, integrated pest management, harvesting and post harvesting technology.

Table - 4.4.7.1: Situation of Agriculture Training

\begin{tabular}{|c|c|c|}
\hline Training provided & No. of Households & Percent \\
\hline Yes & 19 & 42.22 \\
\hline No & 26 & 57.78 \\
\hline Total & 45 & 100.00 \\
\hline
\end{tabular}

Survey: Field Survey, 2016

In this table 4.4.7.1 shows that only 42.22 percent respondents were facilitated from the opportunity of training and about 57.78 were not benefited from such a facility in the study area.

\section{National and International Market}

In the study area, there is great potentiality for coffee farming and producing. Realizing the importance of coffee, Nepalese government and some coffee relates institution has recognized coffee as an important high value crop and has taken some positive step for its market development. The commercial farming of coffee in study area began only 6-7 years ago. The main traders (contractor and mediator) of the study area are districts Co-operative Kavre, Coffee producer Association, Panchkhal Kavre Coffee Company.

Nepal exports only super quality green beans to overseas markets. It doesn't even export medium quality green beans. Medium and low quality green beans are roasted, grinded and sold in the domestic markets. The major brands of the domestic roasted ground coffee are Gourishankar Organic Coffee Association, NECCO, Jalpa Gold, and Himalaya organic coffee. The major markets for the Nepalese green beans are USA, Japan, Netherland, UK, and Germany.

\section{Conclusion}

Although the coffee growers of the study area have been facing many problems, they are still optimistic about better prospects of coffee farming. Moreover, being a highly potential area, the establishment of modern processing factory will accelerate the production speed with the development of better and marketing areas. With the acceleration of coffee 
production, the problem of unemployment, disguised unemployment will be solved and the flow of migration from hills region to Terai will be checked to some extent as the coffee production is labor intensive occupation. Similarly, wide spread support services should be made available at the farm level as an incentive to the farmers; hence the coverage area of coffee orchards will be increased, which will help to maintain environment balance by checking the landslides soil erosion, floods air pollution etc. Thus, the people of the study area should be advised to grow coffee plants in their farms by providing incentives such as giving the economical, technological and other necessary supports by the government.

\section{References}

Bajracharya, P. \& Pathak, K. P. (2001), "An Assessment of CoffeePotential in Nepal, "National Tea and Coffee Development Board. Kathmandu: Nepal.

CBS (2001), "Population Census 2001" Central Bureau of Statistics Kathmandu: Nepal.

Agriculture Development Bank Nepal (1999), "A Study on Coffee Cultivation in Gulmi" ADB, Kathmande: Nepal.

CBS (2003),"Statistical Pocket Book Nepal", Central Bureau of Statistics Kathmandu, Nepal.

DAO (2009), "Annual Progress Report of District Agriculture Development Office", Kavre: Nepal.

DDC (2009),"District Development Committee" DDC Profile, Kavre: Nepal.

FAO (1997), "Agriculture and Food Marketing Management", UN. Rome.

Kurg, C.A. and Poerck, R.A. (1968), "World Coffee Survey" and Food and Agriculture Organization, Rome.

MOAC (2004), "National Agriculture Policy" (APP), Ministry of Agriculture and Co-operatives, Government of Nepal, Kathmandu: Nepal.

MOAC (2008), “National Coffee Policy", Ministry of Agriculture and Cooperatives

MOAC, Government of Nepal, Kathmandu: Nepal.

NPC (2002), "Tenth Plan” (2002-2007\}, National Planning Commission, Government of Nepal, Kathmandu: Nepal.

NTCDB (2064), Chitya Chiya (Tea a Tea), National Tea and Coffee Development Branch Kirtipur, Kathmandu: Nepal.

NTCDB (2067), Tea-Coffee Smarika, National Tea and Coffee Development Board, Central office, Katlmtandu: Nepal.

UN (1971), "The market for Soluble Coffee in Canada and Japan", Geneva:

UNCTADIGATT 